Mykhailo Priymich. Art in Ukraine: questions of meanings, terms and forms

DOI https://doi.org/10.30525/978-9934-26-065-0-13

Mykhailo Priymich,

Dr. Sc. (art history),

Head of Department of Applied Arts

\title{
ART IN UKRAINE: QUESTIONS OF MEANINGS, TERMS AND FORMS
}

\begin{abstract}
The article deals with some issues of development of modern art education and art history in Ukraine, considering the problem of losing the meaning of creative activity and poor development of its own artistic terminology. This is due not only to modern European processes of transformation of values in the view at man, but also the complex historical legacy of education in Soviet Ukraine, where the humanities were subjected to ideological dictate. The service role of the humanities gave it certain state guarantees, because it was here that the justifications of ideological paradigms were forged.

It is obvious that such a state could not but affect the processes in the development of humanitarian knowledge of modern Ukraine, in particular, today we see a huge problem in terminology in various fields. Among these we can highlight the issues of terminology in modern Ukrainian art history. In our review of this problem, an attempt is made to analyze the concepts: fine arts, decorative and applied arts and design. Their different nature is substantiated, which allows us to talk about the need to differentiate approaches to teaching these areas in modern art education and creativity.

Keywords: fine arts, decorative and applied arts, design, word, meaning, nature of origin.

The boundaries of language define the boundaries of consciousness Ludwig Wittgenstein

Theoretical research related to art issues in modern Ukraine often focuses on the exhaustive delineation of a particular phenomenon, or on the justification and its inclusion in the existing system of concepts. Today, the study of theoretical foreign literature, which covers the processes of formation of modern and postmodern art in Europe and America, has become extremely important. This would bring us closer to understanding the problems that are hotly debated in Western societies,
\end{abstract}


avoiding the magical fascination with incomprehensible truths that are borrowed uncritically. Therefore, among the most important tasks we see the need to translate into Ukrainian the basic things on which European art criticism is based today, at least the works of G. Zedelmayer, E. Gombrich, E. Panofsky, V. Gropius and many others. And to approach this important matter, it is necessary to comprehend and develop your own conceptual and terminological apparatus. In our opinion, this should be done not by way of formal borrowing, because it significantly limits the opportunity for improvisation in the Ukrainian environment, but through the development of our own formulations in this area.

Obviously, the problem of concepts and terms is not today's, it is due to the underdeveloped state of the school of art history in Ukraine until the 1990s. It is impossible not to notice the significant steps that have been taken in this direction. Not so long ago, Ukrainian art history was enriched, for example, by thorough work, in which the compiler was R. Yatsiv [4], which systematized the views of Ukrainian scholars, artists and writers on art, or the excellent theoretical contribution of $\mathrm{O}$. Holubets [1], who analyzed the development of world sculpture and a review of Ukrainian works of art against this background. We also want to highlight the work of H. Vysheslavskyi, O. Sydor-Hibelynda [2], where in the form of a dictionary the idea of covering little-understood phenomena in art, such as "alcoart", etc. was embodied. We would like to single out the work of Władysław Tatarkiewicz [8] translated from the Polish, in which an in-depth analysis of the concepts themselves: art, beauty, form, creativity, reproduction, aesthetic experience is made, and their interpretation in different eras. Such research is extremely important because, on the one hand, they form the foundation of our theoretical knowledge about art, and on the other - contribute to the testing and development of artistic terminology in the Ukrainian language environment.

Active work in this field, as well as an attempt to find one's own voice in the world's cultural diversity is of great importance, but in today's dynamic world, this is not enough. The accumulation of knowledge and the development of one's own view of the phenomenon becomes insufficient. Evidence of this is the artistic process in Ukraine, which allows us to say that we are late with generalizations that could become the foundation of their practical use. We notice this both in art education and in the public demand for art - the lack of demand for highly artistic works in the market of services and products. 
With regard to education, we note the lack of clear guidelines and meanings, the achievement of which would be directed to the activities of students, because more and more critical remarks about the sense of the academic study are made. At the same time, we can see that there has also been a transformation in the understanding of the concept of "art" - it has gone beyond aesthetic experience, outlining, to some extent, ethical norms and mainly rational priorities. Focusing on the consumer, trying to attract the interest of the viewer, art has become an action or phenomenon that is presented through the prism of the intellectual paradigm, which gives it the signs of elite secrecy (often artificial). Criticized by Hans Zedelmayer, the assessment of the quality of art through the prism of individual uniqueness, and hence originality, has long slipped as a sign of the artistic level. Originality is not enough. It is no coincidence that today the question arose as to the appropriateness of the very name "fine art". In such a situation, a simple classification of artistic phenomena today will not help to determine the ways in which we should move into the future, because the crisis has affected not only Ukrainian society but also the entire cultural space formed on the basic values of European culture. For this reason, if you do not outline the principles, forms and meanings of activities, it is impossible to develop a system of education.

Of course, this crisis has not happened recently, or there have been some significant changes since the twentieth century. Almost a hundred years ago, Hans Zedelmayer pointed to the profound transformations of European art that he associated with the decline of European values. That is, first of all the problem of the creator, his values and a vital position was considered. However, for the totalitarian society of Soviet Ukraine, the question of freedom of creativity, getting out from under the unifying dictate of ideology has been the main ideal for almost the entire twentieth century. there was. Therefore, freedom of creativity became the main credo for artists in Ukraine in the 1990s. And the spread of liberalism in post-Soviet Ukraine, as a counterweight to totalitarian Leninism, with their basic approach to individual freedom, became an important stream of fresh air for artists. This upset the creative process in the lives of young artists in Ukraine, who opened and are opening unknown spaces of the latest approaches to the creative process and new principles of its interpretation. However, with the freedom of individual there came the second important basis of liberalism - a free market, in which this freedom is realized through the satisfaction of individual 
needs. That is, the market determines the real needs of the individual, which in modern Ukraine has led to the fact that culture has become a non-competitive commodity, for example, theaters barely live on government subsidia, education becomes not an environment shaped by high ideals, but an enterprise producing educational services. And the personality is no longer the basis of the educational process, but at the center is the process itself - the acquisition of skills and theoretical knowledge by a future specialist. That is, it is a question of acquisition of certain functions of the expert. Even the websites of institutions do not brag about who they produce, but about how successful specialists the garduates are. The depersonalization of the individual is taking place, because modern anthropology often considers a human only at the level of a biological being [6], who must acquire a certain amount of practical skills and obtain the appropriate knowledge provided by the program. And the integrity of the person, his ability to individual, not manipulative thinking, remains outside our institutions, because the category of values, in accordance with liberal ideas, is related to the question of the individual.

This situation in Ukraine was caused by another problem, which is conditioned by the service role of the humanities for the ideological foundations of the Soviet value system. In particular, we can safely say this about Soviet historical science, Soviet art history and, obviously, Soviet art in all its manifestations. That is, the applied orientation of these disciplines was aimed at substantiating the ideas of the state order, and less attention was paid to the study of human nature itself, because the concept of man was outlined by the canonical teachings of Karl Marx and Vladimir Lenin. Therefore, it is not surprising that in modern Ukrainian society, which is still largely based on the ideas of dialectical materialism, the concept of humanitarian values causes skepticism even among the humanitarians.

Added to this was a factor shaped by Soviet ideology - the "state of the besieged fortress", which is still manifested in Ukrainian art history, leading to a paradigm - a closed unique culture that lives by its own principles and laws, and any external influences are destructive to it and unwanted. It is important to note that this state is inherent not only in the Ukrainian community in Ukraine, but also in the diaspora [4, Art. 188]. In this case, our judgment is not evaluative, but only a statement of such a phenomenon. At the same time, borrowing external artistic features, rather than changing the approaches themselves, does not change the 
situation in thinking, but to a large extent only causes great problems in the way out of Ukrainian society from the stereotypes of the Soviet paradigm.

For this reason, in search of answers to pressing problems, the thoughts of the Austrian and later American thinker Ludwig Witgenstein are quite interesting. Witgenstein led to the so-called "linguistic turn", when the main focus of researchers was shifted to the study of natural language by rigorous analytical methods. In fact, there is an interesting change in thinking, the emergence of so-called analytical philosophy. Therefore, according to this approach, words should not be understood as symbols of objects, but as a delineation of a concept that was formed by agreement in the process of sharing this object. The thinker believes that at the beginning there is a practice, and only then its delineation and understanding is formed. Developing this idea, we can assume that through language we can understand the nature of the practices that formed the basis of the concept. The meaning of a word in this case is always contextual. Therefore, the purpose of our review will be an attempt to answer the problem of delineating conceptual categories in the art classification.

After all, this problem is long overdue, because the active penetration of new phenomena into the life of Ukrainian society has led to the dominance of foreign vocabulary, which indicates the problem of the reaction of the language environment to new phenomena. For this reason, today we can often notice strange constructs of popular words, which further confuse the understanding of concepts that come only in the form of word marks, because we usually do not understand the context without knowing the language. And all this is happening in a society that is trying to find a way out of ideological terminological clichés that bind their own originality of thinking. Every borrowed word has already found a certain degree of adaptation, for example, "computer", "design", "art group", "art object", "sketching", etc. Along with the dominance of obscure words for the general public, we also see the construction of dubious innovations based on local culture, for example, new absurd definitions such as "intellectual lockdown" or the concept of "ethnic design", the latter may seem very strange to an English-speaking person. Such dominance of the latest terminology testifies to serious problems in cultural development not only of Ukraine, but also of all post-Soviet cultural space.

In view of the above, there is a need to clarify, basing on our own terms, the nature of individual phenomena in art. In particular, we want to dwell on 
the concepts through which the nature of creative search in the fine arts, design and arts and crafts is viewed. Although the term art itself today has no definition of its own.

Thus, we will try to analyze the concepts of "fine arts", "decorative and applied arts" and such a phenomenon as "design". The image the first position in the fine arts, as it is presented in the Academic Dictionary of the Ukrainian language 1970-1980 [7, p. 560]. The first definition is "the appearance of someone or something"; the second - "the appearance of someone or something, reproduced in the mind, memory or created by the imagination"; the third one - "likeness, a copy of someone or something." That is, we can summarize that it is the appearance that I recognize, or my idea of something, or created likeness of something. There is also a definition of the artistic image: it is "specific for literature and art concrete-sensual form of reflection of reality." Thus, the nature of the fine arts is closely linked to the needs of our emotional life, which is inseparable from the need to be reminded of values, ideals, dreams, or from the need for memories, loss, perpetuation, or hope. Obviously, this is where the problem of modern interpretation of the nature of art comes into play, and this is where the way of interpreting the image will come from. However, for our topic it is enough to say that in the fine arts we see a world of ideas, ideals, values, memories. That is, we can say that it is generated by the needs of the human spirit. And according to G. Zedelmayer, we see the highest bursts of this art when the highest achievements in the field of spirit take place.

As for the decorative and applied art, we have its definition in the Dictionary of decorative and applied arts, which states that "decorative and applied art is the art of creating and decorating the products mainly of household character" [3, p. 196-197]. However, in our opinion, in this case it is necessary to talk about its completely different nature, or origin. It is no coincidence that decorative and utility items in the first half of the nineteenth century were not even attributed to art, but rather to craft. Obviously, it is based on a utilitarian component. Taking into account that the tradition of decorative and applied arts is mainly closely related to the life of the rural community, this art (at least in Ukraine) is characterized by the needs and tastes of the rural community. This includes the bourgeoisie of small towns, which lived largely due to the cultivation of land, and therefore preserved with some modifications the tastes of the village population. Therefore, it began to gain more weight due to the development of folklore, which revealed the deep 
meaning of the ritual world of the village, and on the other hand - due to the loss of these things, due to the development of industrial production.

Thus, in this art, shaping is determined by the utilitarian purpose of the thing and the material from which it is made. However, in the rural patriarchal community, where all relations were conditioned by generally accepted ritualistic behavior, each thing also acquired special significance in the relations between individuals. We would like to single out special rituals in the life of a person and society (birth, wedding, death), in which everyday things were also used, for example, the ax, in addition to its direct function in the Hutsul wedding ritual, became an element of ritual. The towel had not only a daily function, but was largely a ritual object. The plate or bowl was also widely used in rituals. In turn, things related to rituals gained special weight, because for a special occasion they were additionally decorated. And since the decorated things acquired a special meaning and prestige, they were stored in the interior for much longer, passed down from generation to generation as valuable not only in memory but also due to decoration. And later, these decorations in certain places of the subject became a kind of tradition, because the decorated items began to come out of everyday life, remaining as things for a special occasion. For example, those were births, engagements, weddings, funerals, no longer taking into account the annual holidays. Therefore, each nation (we mean the rural community), being isolated to a certain extent, was able to create their own decorative system. Making a small conclusion, we can say that decorative and applied art, based on utilitarianism, due to the specifics of the life of population has acquired certain stable forms and decor. That is, decorative and applied art has become a carrier of the tradition of a certain people. Due to the importance of being recognizable, or having a face, decorative arts are unique only when they are marked by a certain formal or decorative tradition. Obviously, we do not rule out the principles of improvisation in this context.

To better understand the specifics of these two types of art, we will try to compare them, taking into account the way they affect the viewer. Fine arts, in order to influence or arouse the viewer's interest, must speak to him in a modern or appropriate language he understands. We can connect with this the process of styles changing, in accordance with the changing of epochs, and views on the world and man. As the epoch changed, so did the form of expression of certain ideals. 
In the old form, although the image remained recognizable, emotionally it became indifferent. Instead, decorative and applied art is interesting and recognizable when it bears the imprint of a certain tradition. Thus, the decorative and applied art has its character when it continues to retain the features of a unique tradition. So, speaking of these two types of art, we emphasize that they evoke emotion and interest in the viewer with signs that are opposite in nature.

Fine art is a modern form in which stable human values are manifested, and decorative and applied art is a recognizable originality of tradition.

Here comes the question of design. An explanatory dictionary of the modern Ukrainian language says that "Design is an artistic constructing and decorating of things (tools, industrial products and interior). The art of design is an artistic and constructing activity aimed at creating new kinds and types of products that would meet the requirements of society (usefulness, ease of use, beauty, etc.). Relevant field of art and scientific knowledge; technical aesthetics ". That is, this phenomenon is generated by the need to respond to the practical and aesthetic (in today's world - fashion) needs of society. Thus, we say, this phenomenon is caused by functionalism in construction and technicalism, technologicalism and constructivism in aesthetics. Therefore, the predominant utilitarianism of this art brings it closer to the phenomenon of decorative and applied arts, but its aesthetic component is conditioned by other factors, namely fashion, which is constantly changing. After all, modern things are woven into the process of trade, which is determined and determines the consumer society. Therefore, the dynamics of formal transformations of modern design is closer to shaping in the fine arts, but these changes are not dictated by a new view on the world, but by new trends in the consumer environment and new technologies, and hence function. That is, we see that the nature of design is markedly different from the above concepts.

Obviously, today there are many definitions of this phenomenon, but the fact of the formation of its modern content in the time of technological progress is indisputable, so its understanding was based mainly on practicality. When we try to understand the development of word semantics today, we see that the English word "design" is of Latin origin from "de + signum" ("signum" - signal, or sign). According to researchers, if we trace the development of the term in the Oxford Dictionary, focusing on the years, then historically the modern concept of "design" 
Mykhailo Priymich. Art in Ukraine: questions of meanings, terms and forms

was as follows: 1548 - "purpose, intention"; 1593 - "a plan in the mind of what will be done"; 1638 - "construction plan"; 1697 - "make a preliminary sketch for the construction of something" [5]. We conclude that there is a tendency: the closer to our time, the vocabulary of this word becomes more specific and, accordingly, narrower. The meaning of activity, defined by this word, on the contrary, is becoming more and more "blurred". Thus, today we have a number of modern concepts related to design, such as "design thinking", "design project" in Ukrainian terminology, and even today we move on to the creation of such a concept as "image in design", although here we mean the appearance of a thing.

In summary, we have reason to say that today the problem of artistic Ukrainian terminology and comprehension of one's own concepts in particular, and those that have already become established in the Ukrainian language, is acute. The problem of meanings in teaching art in art institutions is obvious, which is caused in Ukraine not only by the current crisis of values in Europe, but also by the lack of its own school of humanities. Obviously, we do not want to deny prominent scientists in this field, but rather talk about the problem of our own paradigms in the modern world humanities.

Obviously, our opinions are not the final answers, even to some nuances in the concepts considered, they are rather proposed for discussion and clarification. However, if we take into account the above opinions, the first conclusion is that for each of the phenomena - fine arts, decorative arts and design - should consider a specific program aimed at understanding the nature and principles of formation of these individual branches of modern art.

\section{REFERENCES}

1. Gholubecj O. (2020) Maghija tretjogho vymiru. Skuljpturna plastyka kincja XIX - pochatku XXI st. [The magic of the third dimension. Sculptural forms of the late 19- early 21centuries]. Ljviv: Kolir PRO. (in Ukrainian).

2. Vysheslavsjkyj Gh., Sydor-Ghibelynda O. (2010) Terminologhija suchasnogho mystectva: oznachennja, neologhizmy, zharghonizmy suchasnogho vizualjnogho mystectva Ukrajiny [Terminology of contemporary art]. Paris ; Kyiv : Terra Incognita. (in Ukrainian).

3. Zapasko Ja. (ed.) (2020) Dekoratyvno-uzhytkove mystectvo [Decorative and applied arts] : slovnyk. Ljviv : Afisha, т. 1, pp. 196-197. (in Ukrainian). 
4. Jaciv R. M. (ed.) (2012) Ideji, smysly, interpretaciji obrazotvorchogho mystectva: ukrajinsjka teoretychna dumka XX stolittja [Ideas, meanings, interpretations of fine arts: Ukrainian theoretical thought of the 20 century.] : antologhija : 22 ch. Ljviv. (in Ukrainian).

5. Korolj A. (2012) Sutnistj ponjattja dyzajn i jogho vydy [The essence of the concept of design and its types]. Molodj $i$ rynok [Youth and the market.] (electronic journal), no. 4 (87), pp. 140-145. Available at: http://nbuv.gov.ua/UJRN/Mir_2012_4_35 (accessed 25 July 2021). (in Ukrainian).

6. Sapolski R. (2018) Kto my takie? Geny, nashe telo, obshchestvo [Who are we? Genes, our body, society]. Moskva : Alpina Pablisher. (in Russian).

7. Bilodid I. K. (ed.) (1970-1980) Slovnyk ukrajinsjkoji movy [Dictionary of the Ukrainian language] : in 11 vol. Kyjiv : Naukova dumka. (in Ukrainian).

8. Tatarkevych V. (2001) Istorija shesty ponjatj: Mystectvo. Prekrasne. Forma. Tvorchistj. Vidtvornyctvo. Estetychne perezhyvannja [History of six concepts: Art, Wonderful, Form, Art, Imitation. Aesthetic experience.] / perekl. z poljsjkoji V. Kornijenka. Kyjiv : Junivers. (in Ukrainian). 